\title{
Ulasan Hukum Pidana Sanksi Pada Terumbu Karang Rusak
}

\author{
Siti Afifa Fadillah \\ Mahasiswa Fakultas Hukum, Universitas Negeri Semarang \\ Jl. Kampus Timur, Sekaran, Gunungpati, \\ Kota Semarang, Jawa Tengah 50229
}

Surel: fsitiafifa@gmail.com

\begin{abstract}
ABSTRAK
Masalah yang saat ini belum terselesaikan, yaitu perusakan ekosistem laut yaitu Terumbu Karang. Terumbu karang memiliki banyak peran penting dalam ekosistem laut. Terumbu karang memiliki 100 tahun untuk mencapai ketinggian 1 meter. Penyebab kehancuran terumbu karang ini ada 2 yaitu: faktor alam dan manusia. Faktor alam juga disebabkan oleh manusia (lagi) yaitu pemanasan global. Tindakan manusia inilah yang sangat suka mengeksploitasi keindahan bawah laut ini, membuatnya hampir menghilang dan sebagian rusak. Tindakan "pemburu" itu memang tidak terasa dampaknya. Namun, mereka yang merasakan cucu kita nanti. Ini benar-benar masalah serius dan setiap perilaku manusia yang merusak terumbu karang baik secara langsung maupun tidak langsung layak dikategorikan sebagai kejahatan luar biasa sebagaimana diatur dalam UU Nomor 27 Tahun 2007. Sanksi yang mereka dapatkan berupa denda dengan jumlah besar dan penjara untuk waktu
\end{abstract}

\author{
RIWAYAT ARTIKEL \\ Article History \\ Diterima : 11 September 2019 \\ Dipublikasi : 25 November 2019
}

\section{KATA KUNCI}

Keywords

Hukum, Sanksi, Terumbu Karang

HOW TO CITE (saran perujukan):

Fadillah, Siti Afifa. (2019). "Ulasan Hukum Pidana Sanksi pada Terumbu Karang Rusak", Lex Scientia Law Review. Volume 3 No. 2, November, hlm. 219-226. 


\section{PENDAHULUAN}

Sebagai negara yang memiliki wilayah laut yang luas, Indonesia sangat kaya akan sumber daya alam di bawah laut. Dengan potensi sumber daya, terutama perikanan laut yang besar, baik dari segi kuantitas dan keragaman. Mengingat wilayah laut Indonesia lebih besar dari luas lahan, membuat sumber daya pesisir dan laut memiliki potensi untuk sangat penting, karena daerah ini adalah di mana interaksi antara ekosistem darat dan ekosistem laut yang sangat dinamis dan berpengaruh, wilayah ini sangat intensif digunakan untuk kegiatan manusia seperti: pemerintah pusat, permukiman, industri, pelabuhan, pertanian dan pariwisata. Hal ini juga dapat digunakan untuk pembangunan di berbagai bidang seperti sosial, ekonomi, budaya, dan lingkungan (Adilah, 2017: 1).

Terumbu karang secara umum dapat dikaitkan dengan struktur fisik bersama dengan ekosistem yang menyertainya yang secara aktif membentuk sedimen kalsium karbonat akibat aktivitas biologi yang berlangsung di bawah permukaan laut. Untuk ahli geologi, terumbu karang merupakan struktur batuan sedimen dari kapur (kalsium karbonat) di dalam laut, atau disebut singkat dengan terumbu.

Terumbu karang memiliki fungsi yang sangat penting bagi kehidupan laut. Terumbu karang adalah habitat bagi berbagai spesies laut tanaman, hewan laut, dan mikroorganisme laut lainnya yang belum diketahui. Namun keindahan ekosistem laut di Indonesia semakin terancam, akibat aktivitas manusia yang tidak takut sanksi hukum yang mereka dapatkan dan juga tidak peduli tentang ekosistem bawah laut.

Isu keberlanjutan (atau lebih tepatnya kerusakan) terumbu karang merupakan salah satu masalah lingkungan yang serius. Tentu, banyak masalah dan penyebab hilangnya terumbu karang secara lokal maupun global. Seperti halnya penyakit, sedimentasi, spesies migrasi, bleaching, predator, karang berpori (osteoporosis karang), pertumbuhan alga, dan badai. Selain itu, perubahan iklim global juga penyebab hilangnya terumbu karang. Stres dalam bentuk panas, dingin, terang, dan gelap, terutama meningkatnya suhu air laut menyebabkan kerusakan pada simbiosis antara karang dan ganggang di karang (zooxanthella).

Karbon dioksida dilepaskan ke atmosfer lebih dan lebih kembali ke laut melalui air hujan dan mengubah $\mathrm{pH}$ (keasaman) air laut ke dalam lebih rendah atau lebih asam. Penurunan $\mathrm{pH}$ air laut menyebabkan karang menjadi keropos. karang berpori ini jika kembali ke kondisi air laut yang asli tidak dapat memperbaiki karang lagi.

Semua masalah ini dan penyebab diperparah oleh aktivitas manusia yang menggunakan bahan peledak, bahan kimia, dan alat tangkap untuk memancing yang menyebabkan karang rusak dan kegiatan penambangan timah di daerah pesisir.

https://journal.unnes.ac.id/sju/index.php//sir/

Copyrights (C) 2018. UKM Lex Scientia, Fakultas Hukum Universitas Negeri Semarang 
Tindakan mereka, seperti penangkapan ikan dengan bom atau racun sianida, berdampak pada kehidupan terumbu karang, pengerukan karang di sekitar karang tanpa berpikir tentang ekosistem bawah laut. Namun, sekali lagi perilaku atau perbuatan manusia, terutama untuk lingkungan hampir tidak dirasakan sebagai hasilnya dalam sekejap, tapi bertahun-tahun, bahkan ratusan tahun sesudahnya.

Kerusakan dan hilangnya terumbu karang adalah suatu bentuk aktivitas manusia. Manusia yang melakukan kegiatan seperti eksploitasi masih kurang peduli tentang apa yang telah diatur dalam Undag-Undang Nomor 32 Tahun 2009 tentang Perlindungan dan Pengelolaan Lingkungan mengatur kerusakan terumbu karang. Bahkan, sanksi sudah ditulis dengan jelas.

Jadi apa yang dijelaskan di atas menjadi kebijakan hukum pidana dalam proses pemecahan kerusakan atau kehilangan terumbu karang. Dalam jurnal ini, saya pertama kali akan membahas Pentingnya terumbu karang, faktor-faktor, konsekuensi hukum dari kerusakan atau kehilangan Terumbu karang, dan beberapa solusi.

\section{Rumusan Masalah}

1. Bagaimana kajian Hak Asasi Manusia dalam perspektif hukum positif?

2. Bagaimana kajian Hak Asasi Manusia dalam perspektif hukum progresif?

\section{Metode Penulisan}

1. Pengumpulan Data

Metode Studi pustaka, dimana pengumpulan informasi yang dibutuhkan dilakukan dengan mencari referensi-referensi yang berhubungan dengan penelitian yang dilakukan, referensi dapat diperoleh dari buku-buku, jurnaljurnal atau internet.

2. Sumber Data

Sumber Data Sekunder, diperoleh dari buku-buku literatur dan jurnal ilmiah.

\section{PEMBAHASAN}

\section{A. Perikanan dan Terumbu Karang}

Dalam kamus istilah perikanan, definisi perikanan adalah usaha perikanan yang timbul dan berkembang atas dasar motif ekonomi yang bentuk bisnis selalu diarahkan pada efisiensi maksimum mungkin dengan didukung oleh modal yang relatif kuat. Tujuan ini diwujudkan dalam bentuk kemampuan modernisasi yang lebih tinggi dan keuntungan adalah ukuran utama dari bisnisnya.

Sementara dalam Undang-Undang Nomor 45 Tahun 2009 tentang Perikanan dalam Pasal 1 ayat (1) menyatakan bahwa:

"Perikanan adalah semua kegiatan yang berhubungan dengan pengelolaan dan pemanfaatan sumber daya ikan dan lingkungannya 
mulai dari praproduksi, produksi, pengolahan, pemasaran, dilaksanakan dalam sistem bisnis perikanan".

Itu berarti perikanan dapat dirumuskan hanya sebagai berikut, Perikanan adalah kegiatan atau usaha yang dilakukan oleh manajemen dan ekonomi sumber daya ikan (Leonardo, 2017: 9).

Selain menjadi sumber perikanan, terumbu karang memberikan penghasilan antara lain bagi dunia industri ikan hias, terumbu karang juga merupakan sumber devisa bagi negara, termasuk usaha pariwisata yang dikelola oleh masyarakat setempat dan pengusaha wisata bahari. Jika terumbu karang memiliki fungsi penting bagi ekosistem laut, kerusakan terumbu karang berarti ancaman bagi satu sumber makanan bagi manusia. Tapi kita bertanya-tanya, degradasi terumbu karang terus ngebut yang saat ini hanya sekitar 30 persen dalam kondisi baik.

Coral Reef memiliki pertumbuhan yang sangat lambat, yaitu antara 0,05-0,25 $\mathrm{cm}$ per tahun, sedangkan jenis karang yang memiliki pertumbuhan tercepat sekitar 10-15 cm per tahun. Umumnya, hewan-hewan karang memakan waktu sekitar satu tahun untuk tumbuh bercabang, mencapai sentimeter panjang. Jadi bisa dibayangkan, 1 meter dari batu yang terbentuk dalam waktu yang sangat lama, 100 tahun (Move Indonesia, 2007: 11).

\section{B. Pentingnya Terumbu Karang}

Selain sebagai sumber makanan, sumber pendapatan dan keindahannya, terumbu karang merupakan habitat penting yang dibutuhkan untuk mendukung kehidupan ribuan spesies laut. Terumbu karang melindungi pantai dari badai laut dan angin topan, menyediakan perairan lebih tenang untuk pertumbuhan lamun dan mangrove. Sepertiga dari garis pantai tropis terbentuk oleh terumbu karang (Angela \& Diana, 2012: 22). Terumbu karang harus dilindungi karena peran besar mereka untuk hidup di dunia. Jadi, apa yang penting dari Terumbu Karang?

1. Karang adalah sumber pendapatan. Mengapa terumbu merupakan sumber penghasilan? Karena:

a. Memancing Commercial menyediakan makanan, pekerjaan dan pendapatan sebagai bagian dari pasar makanan laut global (Fishing Industry).

b. Ratusan juta orang bergantung pada ikan karang sebagai sumber utama protein (Fishing local).

c. Tourism bisa mendatangkan pendapatan bagi masyarakat dukungan, mereka hanya ingin Skin diving atau snorkeling, SCUBA Seperti di Kepulauan Komodo, Raja Ampat, dan tempat kecantikan untuk melihat Terumbu Karang di Indonesia. (Industri Pariwisata). (Amin, 2009: 4).

2. Coneshell racun sedang diselidiki untuk digunakan potensi mereka dalam pengobatan untuk menghilangkan rasa sakit. (Sumber Product) 
3. Karang bertindak sebagai pemecah gelombang alami yang orang melindungi dan rumah dari badai dan gelombang. (Shoreline Protection)

\section{Faktor Kerusakan Terhadap Batu Karang}

Sebagian besar kerusakan terumbu karang disebabkan oleh manusia, dan sebagian kecil tidak terjadi karena sifat (Yusri, Safran et al, 2016: 21). Terumbu sehat membutuhkan keseimbangan yang tepat dari sinar matahari, suhu, dan kualitas air. Mengubah kondisi ini dapat merusak kesehatan karang. Jika parah, seluruh terumbu dapat dihancurkan. terumbu Indonesia adalah rumah bagi keanekaragaman hayati yang kaya. Tapi, lebih dari tiga perempat dari terumbu karang di Indonesia beresiko. Dan karena Indonesia bergantung pada terumbu untuk makanan dan pendapatan, itu adalah rentan terhadap efek dari degradasi karang. Beberapa kerusakan terumbu adalah dari peristiwa alam seperti badai. Namun, banyak dampak negatif pada terumbu disebabkan oleh aktivitas manusia. Langkah pertama untuk meningkatkan kesehatan terumbu adalah untuk mengidentifikasi bagaimana mereka dipengaruhi oleh aktivitas manusia. Penyebab kerusakan tersebut meliputi:

1. Merusak Fishing Praktek dan Penangkapan ikan berlebihan.

Overfishing dan penggunaan metode penangkapan ikan yang merusak sangat merusak terumbu karang. Pengeboman ikan dan membunuh racun ikan lebih dari sekedar ikan ditargetkan teknik ini membunuh spesies lainnya termasuk karang. Di beberapa daerah, pengeboman ikan telah menghancurkan $80 \%$ dari karang. Penangkapan berlebih dapat mengurangi jumlah ikan yang memakan ganggang dan membuat karang lebih berisiko pertumbuhan berlebih alga.

2. Sedimen dan Polusi.

Menjaga terumbu sehat tidak hanya melibatkan laut. Apa yang kita lakukan di darat juga penting. Karang membutuhkan air bersih, gizi-bebas untuk menjadi sehat. Tingginya kadar pembangunan pesisir dapat meningkatkan kadar sedimen dan nutrisi cuci dari tanah ke laut. Pembangunan daerah pedalaman juga mempengaruhi karang. Pupuk dari peternakan bisa masuk sungai dan mengalir ke laut. Deforestasi dapat meningkatkan cuci sedimen ke sungai dan kemudian ke laut. Sedimen menutupi karang, memblokir akses mereka terhadap cahaya. Nutrisi seperti pupuk mempromosikan pertumbuhan alga yang bersaing dengan karang. Yang ini seperti: Sampah dan bentuk lain dari polusi bisa mencuci ke laut dari tanah atau dari industri pelayaran, Sampah dan bentuk lain dari polusi bisa mencuci ke laut dari tanah atau dari industri perkapalan, konstruksi bangunan di daerah pantai Nusa Dua, Bali , Indonesia. 
3. Polusi Air

Industri manusia dibangun menggunakan sungai sebagai tempat pembuangan limbah. Banyak dari limbah beracun dan menyebabkan kematian terumbu karang dan biota laut lainnya.

4. Kegiatan Boat

Aktivitas manusia dalam berperahu juga membuat banyak kerusakan pada terumbu karang. Penggunaan jangkar untuk parkir perahu, berperahu di daerah karang dangkal, penggunaan bambu untuk perahu propulsi mengarah ke patah dan rusak terumbu karang.

5. Ancaman dari Alam

Sementara ancaman dari alam yang mengancam terumbu karang meliputi badai, gelombang pasang, badai, tsunami, gempa bumi, letusan gunung berapi dan predasi oleh COTS (crown-of-duri bintang laut) atau umum dikenal sebagai bintang laut.

6. Pemutihan Karang dan Pengasaman Laut

Perubahan iklim yang disebabkan oleh pemanasan global yang terjadi di bumi yang disebabkan oleh manusia yang mengabaikan lingkungan. perubahan iklim, yang menyebabkan perubahan suhu air laut. Karena karang tidak kuat akan perubahan suhu di laut dan menjalani perubahan kita biasanya tahu proses pemutihan (Dahlah, Netty et.al, 2015: 93-93). Increasing emisi karbon dioksida $\left(\mathrm{CO}_{2}\right)$ ke atmosfer tidak hanya mengubah iklim itu juga mempengaruhi terumbu kami dalam banyak cara. Emisi $\mathrm{CO}_{2}$ yang lebih tinggi terkait dengan suhu laut yang lebih tinggi. Dan, suhu laut yang lebih tinggi dapat menyebabkan pemutihan karang. Perubahan iklim juga dapat meningkatkan intensitas siklon, meningkatkan daya mereka untuk merusak terumbu karang. Lautan menyerap karbon dioksida dari udara. Sebagai emisi $\mathrm{CO}_{2}$ meningkat, ini perubahan kimia laut, membuatnya lebih asam. Ini disebut pengasaman laut. Lautan lebih asam memiliki lebih sedikit karbonat di dalamnya. Karena karang perlu karbonat untuk pertumbuhan tulang keras mereka, memperlambat ini turun pertumbuhan karang. 


\section{Penegakan Hukum di Terumbu Karang}

Terumbu karang adalah salah satu ekosistem yang terkait dengan perikanan resources. Ini sehubungan dengan terjadinya pelanggaran perusakan terumbu karang secara langsung atau tidak langsung, lebih tegas dan berat sebagaimana diatur dalam UU Nomor 27 Tahun 2007 (Ida \& Riski, 2016: 13). Dalam Undang-Undang Nomor 27 Tahun 2007 terhadap orang-orang sengaja terlibat dalam kegiatan penambangan karang, mengambil terumbu karang di kawasan konservasi, dengan menggunakan bahan peledak dan bahan beracun, dan/atau cara lain yang mengakibatkan rusaknya ekosistem terumbu karang dalam bentuk perbuatan:

1. Pertambangan terumbu karang yang menyebabkan kerusakan ekosistem;

2. Terumbu karang;

3. Mengambil terumbu karang di kawasan konservasi;

4. Menggunakan bahan peledak, bahan beracun, dan/atau bahan lain yang ekosistem terumbu karang kerusakan;

5. Menggunakan alat-alat lain, metode dan metode yang ekosistem terumbu karang kerusakan;

Tindak pidana karena melanggar Pasal 73 ayat (1) huruf a jo UU Nomor 27 Tahun 2007 tentang Pengelolaan Wilayah Pesisir dan Pulau-Pulau Kecil dan Penerapan Ketentuan Pidana Terhadap Pelaku Destruction Kejahatan Ekosistem Terumbu Karang yang tepat dan sesuai dengan rumusan dalam Pasal 73 ayat (1) huruf a jo UU Nomor 27 Tahun 2007 tentang Daerah Pengelolaan Pesisir dan Pulau-Pulau Kecil. Dengan pidana penjara selama 2 (dua) tahun, dan denda Rp2,000,000,000.00 (dua miliar rupiah).

\section{E. Solusi Ini Untuk Perlindungan Terumbu Karang}

1. Melibatkan masyarakat pesisir secara langsung dalam upaya melestarikan lingkungan air terumbu karang.

2. Menetapkan kontrol pesisir dan laut masing-masing daerah di bawah Kantor kelautan dan perikanan (Rizky, 2013: 72).

3. Sering mengendalikan kondisi perairan terumbu karang.

4. Aktif dalam menjaga dan mempertahankan perairan laut, khususnya terumbu karang.

5. Menyediakan konseling fungsi ekologis tetangga terumbu karang sehingga orang diharapkan menyadari pentingnya terumbu karang.

6. Memberikan sanksi yang cukup tegas dan berat bagi masyarakat untuk melanggar peraturan tentang konservasi dan perusakan terumbu karang.

\section{KESIMPULAN}

Terumbu karang secara umum dapat dikaitkan dengan struktur fisik bersama dengan ekosistem yang menyertainya yang secara aktif membentuk sedimen kalsium karbonat akibat aktivitas biologi yang berlangsung di bawah permukaan 
laut. Untuk ahli geologi, terumbu karang merupakan struktur batuan sedimen dari kapur (kalsium karbonat) di dalam laut, atau disebut singkat dengan terumbu. Coral Reef memiliki pertumbuhan yang sangat lambat, yaitu antara 0,05-0,25 cm per tahun. terumbu karang harus dilindungi oleh hukum yang kuat seperti di tindakan kriminal karena melanggar Pasal 73 ayat (1) huruf a jo UU Nomor 27 Tahun 2007. Meskipun kerusakan terumbu karang adalah karena faktor alam. Kita semua harus bisa mengurus terumbu karang. Bahkan tidak menambahkan eksploitasi. karena menganggap sudah rusak.

\section{DAFTAR PUSTAKA}

Amin. 2009. Terumbu Karang; Aset Yang Terancam (Akar Masalah dan Alternatif Solusi Penyelamatannya). Region I (2): 1-12.

Angela. D. dan Diana Kleine. 2012. Coral Reefs and Climate Change. Australia: The University of Queensland.

Dahlah, Netty. et.al. 2015. Kerusakan Lingkungan Akibat Aktivitas Manusia Pada Ekosistem Terumbu Karang. Yogyakarta: Universitas Gajah Mada.

Helga Adillah, Andi. 2017. Tinjauan Yuridis Terhadap Tindak Pidana Pengrusakan Ekosistem Terumbu Karang Di Dalam Kawasan Konservasi. Makassar: Universitas Hasanudin.

Ida \& Riski. 2016. Pengaturan Internasional Vandalisme Terhadap Terumbu Karang Di Indonesia. Fakultas Hukum: Universitas Udayana.

Kastanya, Leonardo. 2017. Sanksi Pidana Terhadap Pelaku Tindak Pidana Pencurian Ikan dan Terumbu Karang, Jurnal Kertha Wicaksana. Vol 1 (5). Fakultas Hukum: Universitas Warmadewa.

Pindahkan Indonesia. 2007. Ada Apa Dengan Terumbu Karang ... ??. Republika. Diakses dari https://www.google.com/amp/s/m.republika.co.id/amp/or6px4361.

Rizky. 2013. Dampak Pencemaran Lingkungan Laut Oleh Perusahaan Pertambangan Terhadap Nelayan Tradisional, Lex Administratum. Vol 1 (2).

Yusri, Safran. et al. 2016. Rencana Aksi Nasional Konservasi Karang. Direktorat Konservasi dan Keanekaragaman Hayati Laut: Kementerian Kelautan dan Perikanan. 